\title{
A Diachronic Analysis of the Lancashire Dialect in Beckside Lights (1897) by John Ackworth (1854-1917)
}

\author{
Nadia Hamade Almeida \\ University Complutense of Madrid, Madrid, Spain
}

\begin{abstract}
This paper deals with the dialect in the novel Beckside Lights (1897) by John Ackworth. It is a literary dialect which attempts to suggest the speech of the Bolton (Lancashire) area. As a complete research of this dialect is beyond the scope, I aim to analyze some deviant spellings which affect words containing some RP long vowels /i:/, / :/, /з:/ and /a:/. A historical insight is provided to indicate the possible origins of the pronunciations suggested by the author. The findings of this study reveal important data. According to the EDD, most of the pronunciations here suggested are present in Lancashire. Many of them are also present in other northern counties, but barely in Scotland and the southern part of England. On the other hand, Graham Shorrocks in his study of the Bolton area does not provide similar pronunciations in all cases. As for the words here presented, Joseph Wright attests most of them in the EDD. Nevertheless, the EDD and the web search are fruitless in other words.
\end{abstract}

Keywords: literary dialect, dialect literature, Lancashire dialect, John Ackworth, Beckside Lights

\section{Introduction}

The portrayal of dialect in literature is divided into two categories, dialect literature and literary dialect. The former is related to those novels, plays and poems composed totally in dialect. This literary genre is supposed to be addressed to a limited number of readers; those readers who can understand the dialect portrayed. Consequently, this literary genre cannot be understood by a wide audience. This concurs with what Brook (1963, p. 189) affirms, "If a reader unfamiliar with the dialect is willing to go to the trouble of looking up in a dictionary the meanings of unfamiliar words, he cannot appreciate the author's full effect". On the contrary, literary dialect refers to the representation of vernacular speech in literature. It is especially used to mark the discourse of one or various characters. Literary dialect may also be the author's attempt to represent in writing a language which is limited to a region or particular social context. But, in general, both literary genres are considered to be two valuable sources that help broaden the knowledge of the phonology, morphology, lexis and syntax of a specific dialect.

The Lan dialect has been, along with the Yks dialect, the most represented in English literature. Beckside Lights (1897) (hereinafter BL) is a clear example of literary dialect and it attempts to portray the dialect of the Bolton area. The dialect represented, which is used by the different characters, resembles casual speech with several cases of colloquialisms. As a literary dialect novel, instances of eye-dialect are likely to be found

Nadia Hamade Almeida, master's degree in Advanced English Studies: Languages and Cultures in Contact, Department in English Linguistics, University Complutense of Madrid.

Correspondence concerning this article should be addressed to Nadia Hamade Almeida, Calle Huertas de Arenales, $\mathrm{n}^{\circ} 4,1^{\circ} \mathrm{J}$, post code: 49023, Zamora, Spain. 
throughout it. Eye-dialect is a literary technique which consists of the use of a non-standard spelling to suggest a SE pronunciation. Writers are not linguists and, thus, they are not exhaustive trying to reproduce the dialect in their writings. This technique also helps readers not to lose interest since eye-dialect only purpose is to remind readers about characters' speech habits. Furthermore, as authors want their novels to be understood by as many readers as possible, try to suggest the dialect pronunciations by means of deviant spellings, which, as Brook (1963, p. 189) considers, are "semiphonetic spellings". However, there is not a uniformity in the spellings used by the different authors. This results in a great variation in the orthography employed.

This paper attempts to study how the Bolton dialect is represented in the novel BL (1897) by John Ackworth (1854-1917) (hereinafter JA). As there is not enough space to analyse the entire dialect, this paper is focused on some specific aspects of it. The aim of this study is to analyse some of those deviant spellings which seem to affect the RP long vowels /i:/, / :/, /3:/ and /a:/. For this purpose, I have selected some words containing the spellings which affect the aforementioned RP vowels. A research based on the English Dialect Dictionary (EDD) and English Dialect Grammar (EDG) is also provided. It is intended to show the pronunciation these words had in the area and if the deviant spellings are recorded in other writings.

\section{The Lancashire Linguistic Panorama}

Lan is a county located in northern England. Its dialect has been frequently studied in the past 300 years. The Lan dialect is considered to be very heterogeneous. The mixing of the population in Lan, due to the spread of cotton-manufacture, triggered the deterioration in the purity of the Lan speech. The cotton manufacture began in Britain and pioneered the industrial revolution. By the end of the 19th century, there were more than 2,600 cotton mills in Lan which implied an increase of the population since they employed 440,000 people in the county. Hence, the great dialectal variety, prompted by the cotton manufacture, makes it impossible to determine the boundaries of demarcation.

Furthermore, the Lancashire dialect should not be considered a pure northern dialect, but a mixing of both: the northern dialect and the West Midland dialect. A. J. Ellis (1889, p. 352) in his Early English Pronunciation locates the places of Lonsdale and north and south of the Sands in the Northern English Dialect group (along with the counties of Westmorland, Cumberland, and portions of Durham and Yorkshire), and the rest of Lancashire is located in North-Western English Dialect group (together with Derbyshire, Cheshire, and Shropshire).

There are distinctive dialect areas within the entire county. By the 1850s, Lan witnessed the emergence of town dialects with the only exception of Manchester due to its mixed population. The differences found between the dialect of Lonsdale and that of s and e Lan are not so great than those noticeable within se Lan. One of these se areas is Bolton where its dialect is discernible from Rochdale, Oldham, Ashton-under-Lyne, and Stalybridge.

As far as Bolton is concerned, it is an area of relatively unbroken settlement. It seems practically impossible to predict where its cultural unit ends. As a consequence, it is also impossible to delimit the dialect of the Bolton area from a geographical perspective. The speech of this area is so homogeneous that it is very difficult to provide any difference in pronunciation to determine a variety. Only those who know the dialect can understand and distinguish the possible variations.

\section{John Ackworth (1854-1917)}

JA is the pen name of Reverend Frederick Robert Smith. He was born at Snaith, Humberside in the East 
Riding of Yks in 1854. Snaith was close to the hamlet of Ackworth from which the author probably took his name.

JA was an English novelist who represented the dialects of Yks and Lan in his novels. In a 1906 article, he is quoted as saying that the Danes deeply influenced the English language through the early landings and invasions in England and that,

So strong is the English of the east coasts of England impregnated with Danish that I am sure that if a fisherman from the east coasts of England were to be wrecked on the shores of Denmark, and he would only speak in his true native dialect, that fisherman would be able to make himself understood. (The Saline Observer)

He was not only interested in the dialects of Yks and Lan but also in the study of the speech in the east coasts of England and especially of the Danes. JA was convinced that the Danes and the British are very similar in speech and language.

JA was the son of a family of preachers. He followed the calling and decided to undertake his theological training at the Wesleyan College in Headingley. In 1876, he entered as a minister in the Wesleyan College before being appointed to Castletown, in the Isle of Man. As Wesleyan Ministers could not remain in only one chapel for more than three years, he travelled to other cities. These places included Bolton, Sheffield, Manchester, Lytham, York, St. Helens, Eccles and finally Burnley in 1909 where he finally settled and succeeded the Reverend J. H. Corson.

After three years, he decided to retire from active work, but remained in Burnley as a supernumerary. As a preacher, JA was considered one of the most able within Methodism. His well-arranged sermons were considered to contain ripe wisdom without being dull or monotonous.

Frederick Robert Smith came to be known as the author of very popular tales of Lan working-class folk. His first attempts in writing were in the Isle of Man, a fact he later acknowledged in The Methodist Magazine. However, it was with the consecutive works of Clog Shop Chronicles (1896), Beckside Lights (1897), Doxie Dent (1899), Scowcroft Critics and Other Tales (1898), The Minder: The Story of the Courtship, Call, and Conflicts of John Ledger, Minder and Minister (1900), The Coming of the Preachers: A Tale of the Rise of Methodism (1901), The Mangle House: A Lancashire Tale (1902), From Crooked Roots (1903), that he became a well-known author, especially with Clog Shop Chronicles (1896).

Clog Shop Chronicles (1896) is a collection of 12 Methodist short stories which portray scenes of Lan working-class life and dialect humour. This book also recounts the everyday events which take place in the mythical cotton-mill villages of Beckside, Scowcroft, Bramwell, etc. Furthermore, the characters which appear in Clog Shop Chronicles (1896) and Beckside Lights (1897) are present in the novel Doxie Dent (1899). The other works also deal with Lan and its ordinary people and also Methodists. The Coming of the Preachers (1901), which is characterized by its entertaining use of the dialect, is about the preaching of two of the characters, John and Charles Wesley.

JA employs Lan characteristics and dialect and tries to present attractive illustrations and anecdotes to engage the reader. Despite not being a Lan man he successfully mastered the Lan dialect becoming a notable author in it. He found that the Lancashire dialect was the appropriate variety to deal with all the human stories his novels portray. All his novels depict working-class characters and deal with the everyday life of the Methodist people. 
Although he sometimes included a word from his native West Riding, he tried to maintain the dialect as accurately as possible. Moreover, he used the dialect in a very economical way, turning to plain English so that those readers who were not familiar with the dialect would not have to resort to a glossary.

\section{Beckside Lights (1897)}

BL revolves around the small town of Beckside which is depicted as a small Lan village situated on the south side of Brogden Clough. The only public buildings in Beckside are a little Methodist chapel, a schoolhouse and a Clog Shop which is the central place in the story. Jabez Longworth, better known as "OwdJabe", is the chief official at the chapel and he works with his assistant Isaac. The characters Long Ben and Sam Speck, featured as a carpenter and a henchman respectively, work for Jabez Longworth and Isaac in the Clog Shop. The characters Lige, the road-mender, Jonas Tatlock, the choirmaster, Nathan the smith and Jethro, the knocker-upper do not work in the Clog Shop but they are important in the novel. As Jabez Longworth is an assertive person, the Clog Shop becomes the place where all these characters congregate whenever convenient to talk about the topics the village life provides. Therefore, BL deals with all the circumstances and conversations connected to the village and especially with the different characters.

The exact identification of Beckside is difficult. Boothstown and Stoneclough have been suggested in the last few years as possible locations. Stoneclough is the village which seems to be the most likely place for Beckside since it appears to fit with the description given in BL. At the very beginning of the novel, readers are told that the dialect shown in the volume is that spoken in the area of Bolton. Stoneclough is a suburban area located in the area of Bolton. This could be one of the reasons why Stoneclough seems to be the original village for Beckside.

Identification of the different characters is a different issue. Although little is known about them, some characters are believed to be fictitious while others could be real. It is said that some of them were based on well known personalities of the St. Paul's chapel at Swinton.

$\mathrm{BL}$ is written as a third person narrative which describes the characters and situations. The novel is written in SE except when the different characters, who use the dialect of the Bolton area, intervene. The dialect used in the novel resembles casual speech and includes instances of eye-dialect and colloquialisms. Cases of eye-dialect are among many others, $<$ bin $>$ for $<$ been $>$, <enuff $>$ for $<$ enough $>$, $<$ wot $>$ for $<$ what $>$. Finally, among the spellings indicating colloquialisms are $<\mathrm{an}^{\prime}>$ for $<$ and $>, \mathrm{i}^{\prime}>$ for $<$ in $>,<$ ne'er $>$ for $<$ never $>$.

\section{Linguistic Analysis}

\section{Spellings Which Seem to Affect RP [i:]}

The spelling <eea $>$ seems to suggest $[\mathrm{r}$ ə]. $<$ dreeam $>$, <leeave $>$, $<$ leeavin'>

The spelling $<$ eea $>$ does not exist in SE orthography. $<$ ee $>$ or $<$ ea $>$ are normally used to represent [i:]. The author may have employed <eea $>$ to suggest a diphthongal pronunciation, most probably [iə]. A reader familiar with the Lan dialect would probably interpret it as [гə]. These words in the Lancashire dialect could have had the same phonological developments that happened in the prestige dialect. The only difference is that these words present the glide [ə]. On the contrary, In RP [ 1 ə] and the other centering diphthongs originated due to the process called r-gliding which took place in the 18th century. This dependent change required the presence of $/ \mathrm{r} /$ in the next syllable. Obviously, it is impossible to determine this by means of a deviant spelling unless the word contains $/ \mathrm{r} /$. Therefore, this must be the reason why JA chose this convention; it would not be too confusing for standard readers and quite clear for those familiar with the Lan dialect. 
In dream,leave and leavin', the spelling <ea> show the ANC convention used to indicate $\mathrm{ME}$ [e:]. Its reflex in PdE is [i:], after passing through the stage [e:] in the 17th century. In Lan [ $\varepsilon$ :] became the diphthong [ ə] in around approximately 1500 (Orton, 1933, p. 349).

GS does not give evidence of the pronunciation / $/$ a $/$ in $<$ dream $>$, < leave $>$ and $<$ leaving $>$, but he records a pronunciation with / / I / in <leave > and in other similar words, such as "meat" /m $\varepsilon_{\mathrm{It}}$ / or "lean" /le In/.

EDG records [ s Oxf.; in $<$ leave $>$ and $<$ leavin'> it is attested for swNhb, n Yks, se Yks, swYks and Lan. Interestingly enough, it records [ $\mathrm{I} a]$ in $n$ Lan.

EDD does not record the spelling < dreeam>, but a web search attests to its use in texts from Lan (Songs and Lyrics (1922) by George Hull (1863-1933)), (Gooin'to Cyprus (1850) by Benjamin Brierley (1825-1896) (hereinafter BB)), (Ab-o'th-yate at the Isle of Man (1869) by BB) and Yks (Poems in the North Yorkshire Dialect (?) by John Castillo (hereinafter JC) (1792-1845)), (The Lucky Dreeam, or an Awd Thing Renewed (1843) by JC (1792-1845)).

As far as <leeave> is concerned, EDD records it in texts from Wm (Aald tales (1882) by Thomson Robinson (?-?)); Yks (Cleveland Rhymes (1875) by GT (1823-1903)), (Studies in Nidderdale (1882) by Joseph Lucas (1834-1902)) and Lan (Layrock of Langleyside. A Lancashire Story (1864) by BB). <leeavin'> does not appear in EDD but a web search shows that the spelling is found in texts from Lan (Ab-O'th-yate at the Isle of Man (1869) and (The Layrock of Langley-side: A Lancashire Story (1864) by BB) and (Bits o'Broad Lancashire (1888) by William Baron (1865-1927)).

The spelling <ei> seems to suggest [ $\left.\mathrm{e}_{\mathrm{I}}\right] .<$ steil $>$, < speik>

The digraph $<\mathrm{ei}>$ does exist in SE. It is used to suggest a diphthongal pronunciation, [e $\mathrm{e}_{\text {I }}$ or [a [ ]. JA may have resorted to that spelling to suggest the diphthong [ $\left.\mathrm{e}_{\mathrm{I}}\right]$ as found in $<$ feist $>$ and $<$ feign $>$. $<$ steal $>$ and $<$ speak $>$ had ME [\&:]. This phoneme became [i:] in PdE after passing through the stage [e:] in the prestige dialect. However, such was not the case for these words. The diphthong suggested could be the result of the same phonological processes of the "face-type". This means that, Middle English [ $\varepsilon$ :] developed into [e:] and later diphthongized into [ $\left.\mathrm{e}_{\mathrm{I}}\right]$. That is to say, these words joined those containing Middle English [a:].

GS attests to the pronunciation /3 I for $<$ steal $>$ and $/ \varepsilon_{\text {I }} /$ for $<$ speak $>$. He also shows that $<$ steal $>$ can have

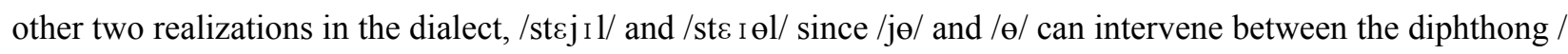
$\varepsilon \mathrm{I} /$ and $/ 1, \mathrm{r} /$.

EDG shows the existence of $\left[\mathrm{e}_{\mathrm{I}}\right]$ in $<$ speak $>$ for s. Yks and se Lan. The variant [ $\mathrm{I}$ ə] is attested in nw and em Lan. In $<$ steil $>\left[\mathrm{e}_{\mathrm{I}}\right]$ is attested in sw and msYks, em Lan. Interestingly enough, [ $\mathrm{I}$ ə] is recorded for sm, sw and s Lan.

EDD does not record <speik> but a web search shows that it appears in texts from Lan (Eawr Sarah's Chap (?) by Clarke Allen (1863-1935) and Yks (Dialect of the West Riding of Yorkshire: A Short Story of Leeds and Other Towns (1891) by Samuel Dyer (?-?)). Finally, EDD does record <steil> in texts from Yks (BairnslaFoaks' Annual: And PogmoorOlmenack (1868) by Tom Treddlehoyle (?-?)).

In any case, the words from sections 5.1.1 and 5.1.2 are all pronounced with the long monophthong [i:] in ME. The distinction in pronunciation between words on section 5.1.1 and 5.1.2 is typical of the North-Midland dialect according to Wakelin (1977, p. 90). He also considers that those words coming from ME [ $\varepsilon$ :] (from OE [æ:] or OE [æa:]) developed into the diphthong [ıə] and those ME words from ME [\&:] (from an early Open 
Syllable Lengthening) derived into the diphthong [EI] (90). These attested pronunciations concur with the origins of the words selected in this study. "Dream" contained [æ a:] in OE, "leave" [æ:], and "speak" and "steal" had the long monophthong $[\varepsilon:]$ in ME due to an early shortening in open syllable.

\section{Spellings Which Seem to Affect RP [ : :]}

The spelling $<$ ooa $>$ seems to suggest [ひə]. $<$ mooar $>$

The spelling $<$ ooa $>$ does not exist in SE orthography. $<00>$ is normally used to represent [u:] or less frequent [U]. The author may have used $<00 a>$ to suggest a diphthongal pronunciation, probably, [u:ə] or [və]. A reader familiar with the Lan dialect would probably interpret it as [0ə]. This word contained the monophthong [ə:] in Middle English. Normally, long vowels were raised in the 15th century due to the Great Vowel Shift. However, when long vowels were followed by -r, this consonant prevented the aforementioned process to happen. The dialectal pronunciation JA suggests probably indicated different phonological processes as those of SE.

The reason of this pronunciation is explained by Dobson $(1968$, p. 675) who points out that ME [o:] raised to [o:] because it was followed by -r. As a result, [o:] developed into [u:] by the Great Vowel Shift. Furthermore, it includes the glide $[\square]$, which in the prestige dialect is seen when there exists the presence of the consonant -r. In this specific case, not only the Great Vowel Shift took place, but also, the following [r] triggered the $[\square]$

This must have been the reason why JA chose this spelling; it would not be confusing for standard readers and clear for those familiar with the Lan dialect.

GS records $/ \mathrm{Ye} /$ in $<$ more $>$. $/ \mathrm{Ye} /$ is a falling centring diphthong. Its first element has a rounded sound but not very strong, but it depends on the phonetic context. The second element is usually higher and more rounded than the second element in other RP centring diphthongs.

EDG records [0ə] in <mooar> in nm, se and swYks, nm, se, sw and s Lan, I. Ma, Chs, ne, em and s Stf, Der, $m$ and s Lin, Lei. $m$ and swNhp, e and s War, $n$ Wor, ne, and e Hrf, Glo, Oxf, Brks, m Bck, Bdf, w and se Hrt, e Suf, n Ken, Sus, smHmp, nw and w Wil, ne and w Som.

Although $<$ mooar $>$ does not appear in the EDD, a web search shows that it appears in texts from Lan (The Weaver of Wellbrook (1854) by BB), (The Song of Solomon in the Lancashire Dialect, as Spoken at Bolton (1859) by James Taylor Staton (1816-1875)) and (Bits o'Broad Lancashire (1888) by William Baron (1865-1927)).

The spelling $<$ ow $>$ seems to suggest $[\mathrm{a} v]$. $<$ browt $>$, $<$ thowt $>$

The spelling $<\mathrm{ow}>$ does exist in SE. It is frequently used to reflect the diphthongal pronunciation [au] as in the words cow, brown, town, owl, etc. However, there are also exceptions such as the words row, know, low, etc., which are not pronounced with [av] but with the diphthong [əo].

JA may have used the spelling $<\mathrm{ow}>$ to suggest the pronunciation [av] which would be evident for SE readers and for those who were familiar with the Lan dialect.

In brought and thought, the spelling $<0 \mathrm{ow}>$ has existed since the ME times to reflect the process known as $h$-gliding. Wells (1982, p. 91) affirms that those words containing the consonant sequence -ought were realized with the diphthong $[\quad]$ which, when followed by $[\chi t]$, underwent a merger with [av]. However, during the seventeenth century, the monophthong [ ] emerged. Wells also asserts that in northern England, those words, which once contained the consonant $[\chi]$, have the diphthong [av] (192). This means that many dialects 
preserved and some still preserve the original Middle English diphthong [av]. This could be because in southern England $[\chi]$ was lost much earlier than in other dialects in northern England.

GS records the pronunciation $/ \varepsilon \mathrm{Y} /$ in $<$ brought $>$ and $<$ thought $>$. $/ \varepsilon \mathrm{Y} /$ is a falling diphthong which in most cases has a starting position around $/ \mathcal{E} / . / \mathrm{Y} /$ as the second element is dictated by the fact that the diphthong moves towards a central position with a degree of unrounding in most cases. The author also provides other similar words which correspond to RP / :/, "fought" /f\&Yt/ and "ought" /\&Yt/.

EDG records [av] in <brought $>$ in s Nhb n Dur + brout $\mathrm{n} \mathrm{Cum}+$ broxt, brout Wm, snwYks + brout, nw Lan, s Lan + brot, brout, n Der. In <thought>, [av] is attested for swNhb, n Dur, Wm, em Lan + pout, se Lan, s Lan + pot, pout. [ov] is also found in sm and sw Lan, ms Lan + pout, s Lan.

EDD records $<$ browt $>$ in texts from Nhb (The Book of Ruth (1860) by Joseph Philip Romson (1808-1870)), Cum (Betty Wilson (1886) by Thomas Farrall (1837-1894)); Lan (Probation (1879) by Jessie Fothergill (1851-1891)), Lin (OwdRoa (1889) by Alfred Tennyson (1809-1892)), and Nrf (The Song of Solomon in the Norfolk Dialect (1860) by Edward Gillet (n.d.)). For the spelling of $<$ thowt $>$, EDD records it in texts from Nhb (Fiddler of Carne (1896) by Rhis, Ernest (1859-1946)), Dur (Kitty Fayan (1900) by James Guthrie (1859-1930)), Cum (Anudder Batch (1873) by Geordie Greenup (n.d.)), Wm (Owd Bob (1898) by Alfred Ollivant (1874-1927)); Yks (Cleveland Rhymes (1875) by GT (1824-1899)) and (Moor and Fell (1899) by Halliwell Sutcliffe (1870-1960)), Lan (Manchester Man (1876) by Isabella Banks (1821-1897)), Der (Willowbrake (1898) by Gilchrist (1867-1917)), Lin (Spinster's Sweet-arts (1885) by Alfred Tennyson (1809-1892)), Nrf (Broad Norfolk (1893) by Herbert Cozens-Hardy (1838-1920)), and Hmp (Lettice Lisle (1870) by Frances Parthenope Verney (1819-1890)).

\section{Spellings Which Seem to Affect RP [3:]}

Eye-dialect. $<$ pupuss $>$, $<$ thurty $>$

The words $<$ pupuss $>$, $<$ thurty $>$ are clear instances of eye-dialect.

Thurty appears only once in the whole novel, "ther'snoabry else played on't for this last thurtyye'r, at ony rate" (Ackworth, 1897, p. 29). However, the standard spelling <thirty > appears three times. As far as pupuss is concerned it appears twice, "he does it o'pupuss" (Ackworth, 1897, p. 13); "If aw thowt he's done that o'pupuss" (Ackworth, 1897, p. 15). Moreover, it is interesting that the word pupuss shows the loss of $/ \mathrm{r}$ / followed by a consonant, which was not common in the representation of the dialect.

EDD does not record either of the words mentioned. Also, a web search was fruitless.

\section{Spellings Which Seem to Affect RP [a:]}

The spelling $<\mathrm{e}>$ seems to suggest $[\mathrm{e}] .<$ efter $>$, < efthernoon $>$

The spelling $<\mathrm{e}>$ is frequently used to suggest the pronunciation [e] as in bed, red, went, set, etc. and [I] as in exam etc. JA probably used this spelling to suggest the pronunciation [e]. The words after and afternoon contain $\mathrm{OE}[\mathfrak{~}]$ which developed into [a] in ME and afterwards into [a:] in certain contexts in the prestige dialect. However, in Lan $\mathrm{OE}[æ]$ did not become [a] but underwent a second fronting into [e], possibly due to Scandinavian influence (Zachrisson, 1913, pp. 60-61).

GS attests to the pronunciation /æ:/ in the word <afternoon $>$ but not in $<$ after $>$. He also gives other words which correspond to RP /a:/ before/f/, such as "graft"/græ:ft/ and "shafts"/

EDG records [e] in <after> in ne and s Nhb, Dur, em and w Cum, Wm, Yks, but e Yks + efp (r), se Yks + aft (r), afp (r), efp (r), sw and s Yks + aft (r), nw Lan, n Lin. 
EDD does not record $<$ efther $>$ or $<$ efthernoon>. However, a web search gives evidence of $<$ efther $>$ in texts from Cum (The History of the County of Cumberland (1794) by William Hutchinson (1732-1814)) and $<$ efthernoon> appears in texts from Lan (The Mangle House (1902) by JA (1845-1919)).

The spelling $<$ ay $>$ seems to suggest $\left[e_{\mathrm{I}}\right] .<$ fayther $>$, < rayther $>$

The spelling $<$ ay $>$ is normally used in SE to suggest the diphthongal pronunciation [ $\mathrm{e}_{\mathrm{I}}$ ], as in play, day, may, etc. JA probably resorted to $<$ ay $>$ to indicate $\left[\mathrm{e}_{\mathrm{I}}\right]$. These two words contained [a] in Middle English, which later became [a:] in Standard English. However, this may not have happened in Lancashire where this short "a" could have experienced an early lengthening and consequently followed the same phonological processes as those face-type words coming from Middle English [a:]. In the case of the word "father", Lodge (1984, p. 19) affirms that there existed three different pronunciations in the area of Manchester, among them there was [fee $\delta]$ from the ME nominative "fader". In this specific case, the short "a" was lengthened because it was in an open syllable. Then, it changed to monophthongal to diphthongal, "along with other words of this type, e.g. name, gate" (19).

GS does not record a diphthong in $<$ father $>$ and $<$ rather $>$ but the monophthong /e:/ in both words.

EDG gives evidence of [ $\left.\mathrm{e}_{\mathrm{I}}\right]$ in $<$ father $>$ in se Lan, $\mathrm{n}$ and emStf + fèðə(r), nw Lin. In $<$ rather $>$, [ $\left.\mathrm{e}_{\mathrm{I}}\right]$ is only recorded in $\mathrm{n}$ Stf.

EDD attests <fayther> in texts from Sc (Daft Davie (1876) by Whitehead (?-?)); Frf (Rosetty Ends, or the Chronicles of a Country Cobbler (1886) by A. Dewar Willock (?-?)) and Per (Ochil Idylls and Other Poems (1891) by Hugh Haliburton (1846-1922)). <rayther> is attested in texts from Lan (Good Owd Toimes (1870) by John L. Owen (1845-1927)).

The spelling $<$ aw $>$ seems to suggest $[0:] .<$ hawf $>$

The spelling $<\mathrm{aw}>$ is frequently used to suggest [o:] as in words such as saw, lawn, jaw, etc. JA probably used this spelling to indicate the pronunciation [o:]. Half comes from ME [a] which later became [a:] in the prestige dialect in certain phonological contexts. This may not have happened in Lan and in general in northern England where the process called l-vocalization took place. This process consisted of the drop of [1], its replacement by the vowel [ $\mho$ ], and later, the consequent monophthongization into [०:]. Although in SE this aforementioned process took place in some $-a l$ and -ol contexts before velar consonants or at the end of a word or morpheme, the deviant spelling JA presents shows that $l$-gliding has taken place. According to this, Wakelin (1977, p. 86) points out that those words containing the sequence [a] $+[1 \mathrm{lf}] /[\mathrm{lm}]$, as in calf, half, palm, "show the regular development of ME al + consonant ... to [०:] in the north and north midlands".

GS attests to the pronunciation $/ \mathrm{s} / /$ in $<$ hawf $>$. He affirms that $/ \mathrm{s} / /$ is extremely rare before $/ 1 /$ due to loss of historical /1/ in the past. GS also indicates that this word can be pronounced with /e:/ and /æ:/ without the glottal fricative $/ \mathrm{h} /$.

EDG records [॰:] in <half $>$ in wmSc, $\mathrm{n}$ Nhb, n Cum, Wm, but $\mathrm{n}$ Wm ōf se and swNhb.

EDD does not record $<$ hawf $>$, but a web search shows that it appears in texts from Cum (The Poetical Works of Robert Anderson, Author of "Cumberland Ballads" (1820) by Robert Anderson (1750-1830)) and Lan (The Lancashire Witches and Teague O'Divelly, the Irish Priest (1682) by Thomas Shadwell (1642-1692)). However, EDD does give evidence of $<$ hauf $>$ in Yks (TheBairnslaFoaks' Annual (1873) by Tom Treddlehoyle $(?-?))$.

The spelling $<$ er $>$ seems to suggest [3:]. $<$ hert $>,<$ herted $>$ 
The spelling <er> is commonly used to suggest [3:] as in her, serve, etc. It also can indicate the pronunciation [a:] as in the words clerk, Derby, sergeant, etc. JA apparently used <er $>$ to suggest [3:]. These words contained the diphthong [eo] in Old English, which later developed into [e] in the Middle English period. In the prestige dialect, the sequence $[\mathrm{e}]+[\mathrm{r}]$ developed into $[\mathrm{a}]+[\mathrm{r}]$ in the 14th century. Finally, this vowel lengthened into [a:]. However, this may not have happened in Lancashire where this aforementioned change may not have happened or, on the contrary, other developments took place. According to this Sánchez (2003: 244) this pronunciation in this type of words responds to a process of centralization. She also considers that as the standard realization is due to a process of retraction, being [er $>æ r>a r]$, the pronunciation [ər], and later [ə:], appeared by means of centralization (244)

GS records / $\Theta$ :/ in the words $<$ hert $>$ and $<$ herted $>$. The author considers / $\Theta$ :/ as a long, rounded vowel. The height of this vowel varies between half-close and half-open and its position can be between front and centre. Consequently, very few realisations of this phoneme are as lax as the RP/3:/. GS also provides evidence of this pronunciation in the words "Derby"/de:(r)b / and "clerk" /kle:(r) k/.

EDG records [3:] in $<$ heart $>$ and $<$ hearted $>$ only in sm Lan.

EDD does not give any evidence of the spelling of $<$ hert $>$ and $<$ herted $>$ in other writings and a web search was fruitless for either word.

\section{Conclusion}

In an attempt to come to a better understanding of the Bolton dialect, this paper has focused on the novel Beckside Lights (1897) which portrays the Bolton dialect. This study has approached some dialectal spellings which affect words containing RP /i:/, / :/, /3:/ and /a:/. I have made a 100-year span comparison of the possible pronunciations JA and GS suggest for the different words. I have also indicated the pronunciation they seem to suggest and the presence of them in other texts. The findings reveal that most of the pronunciations suggested are attested to in Lan and in other different areas. These data appear in Table 1 below.

Table 1

Dialectal Pronunciations Which Affect RP /i:/, /s:/ and /a:/

\begin{tabular}{|c|c|c|c|c|c|c|}
\hline & Lancashire & East Midlands & West Midlands & $\begin{array}{l}\text { Other northern } \\
\text { counties }\end{array}$ & Scotland & South \\
\hline RP /i:/ & /Іә/,/е I/ & / га/ & & /гә/,/е I/,/e/ & & \\
\hline RP / $/ /$ & /va/, /av/ & /Ua/ & /ua/ & /oə/,/av/ & & /Ua/ \\
\hline RP /a:/ & /e I/,/3:/ & & /e//e I/ & /e/ & / :/ & \\
\hline
\end{tabular}

The results above show that most of the pronunciations suggested in this study are present in Lancashire. Many of them are also present in other northern counties, such as Yorkshire, Cumberland, or Cheshire and in less degree in the Midlands where only one or two of these pronunciations are recorded. Finally, Scotland or southern counties barely show these pronunciations.

This study has also shown that some of the words provided are not attested to in the EDD but can be found on the web. This is the case with dreeam, leeavin', speik, mooar, efter, efternoon and hawf. However, hauf is recorded in EDD. In other cases, as in pupuss, thurty, hert and herted EDD and the web search have been fruitless.

To conclude, this paper has been concerned with the Bolton dialect represented in BL. Although this study has not covered the entire dialect, it has provided some insight on the representation of the dialect through some 
of the different deviant spellings affecting words containing some of the RP long vowels. It is hoped that further analysis will be carried out in order to enhance our knowledge and understanding of the Bolton dialect.

\section{References}

Ackworth, J. (1897). Beckside lights. London: Charles H. Kelly. The Salamanca Corpus. U. de Salamanca.

Anonymous. (1906). Retain much of the Danish Speech. The Saline Observer. Michigan Digital Newspaper Portal. CMU Online

Digital Object Repository. Retrieved from http://condor.cmich.edu/cdm/ref/collection/p15076coll5/id/42392

Blake, N. F. (1981). Non-standard language in English literature. London: Deutsch. Print.

Brook, G. L. (1963). English dialects. London: Andre Deutsch. Print.

Dobson, E. J. (1968). English pronunciation: 1500-1700. Oxford: Clarendon Press. Print.

Ellis, J. A. (1889). On early English pronunciation. London: Trubner and Co.

Gibson, A. C. (2008). An introduction to the pronunciation in English. London: Hodder Education. Print.

Hoad, T. F. (Ed.). (1986). The concise Oxford dictionary of English etymology. Oxford: University Printing House. Print.

Lodge, K. R. (1984). Studies in the phonology of colloquial English. Beckenham, Kent: Croom Helm. Print.

Massey, G. John Ackworth. Retrieved from http:/gerald-massey.org.uk/ackworth/

Orton, H. (1933). The history of the stressed vowel-sounds in the Northern English dialects during the modern period. Phonology of a South Durham Dialect 2. (pp. 193-271). London: Kegal Paul. Print.

Sánchez García, P. (2003). Acervo y Tradiciónen la Grafia del DialectoLiterarioen la NovelaInglesaNorteña del Siglo XIX. Salamanca: Ediciones Universidad de Salamanca. Print.

Shorrocks, G. (1998). A grammar of the dialect of the Bolton area. Frankfurt am Main: Peter Lang. Print.

Wakelin, F. M. (1977). English dialects an introduction. London: The Athlone Press. Print.

Wells, J. C. (1982). Accents of English. An introduction (Vol. 1). Cambridge: Cambridge University Press. Print.

Wright, J. (1898-1905). The English dialect dictionary (Vol. 6). London: Oxford University Press. Print.

Zachrisson, R. E. (1913). Pronunciation of English vowels 1400-1700. Göteborg: Wald, Zachrissons Boktryckeri. Print. 